\title{
Terrorism and Organized Crime ${ }^{1}$
}

\section{Sam Mullins and James K. Wither}

George C. Marshall European Center for Security Studies, http://www.marshallcenter.org

\begin{abstract}
This article begins with an assessment of the similarities and differences between terrorists and criminals, including profiles, methods, systems of organization and motives. Notably, the article identifies seven categories of crimes committed by terrorists: 1) Inherent/violent, 2) Preparation/facilitation, 3) Funding, 4) Specialized terrorism offenses, 5) Vigilantism/public relations, 6) Miscellaneous/Spontaneous/Unrelated Offences, and 7) Previous criminal records. Next, the crime-terror nexus is discussed and four types of relationships between terrorists and criminals are identified: 1) Interaction, 2) Appropriation, 3) Assimilation, and 4) Transformation. The article concludes with a discussion of the concept of convergence between terrorism and organized crime, and implications for counter-terrorism and law-enforcement.
\end{abstract}

Keywords: Terrorism, counter-terrorism, organized crime, law-enforcement, crime-terror nexus, convergence.

\section{Introduction}

There is little question that criminal activity has been and continues to be a lucrative source of funding for all kinds of terrorists. However, there is still ongoing disagreement about the extent of overlap between the worlds of terrorism and organized crime $(\mathrm{OC})$. Confusion over the nature of the threat in turn acts as a barrier to developing more effective countermeasures. This article attempts to clarify the situation, beginning with an examination of the similarities and differences between terrorists and criminals, including profiles, methods, systems of organization, and motives. In other words, the who, what, how and

1 This article has been adapted from Sam Mullins, James K. Wither, and Steven R. Monaco, "Terrorism and Crime," in Combating Transnational Terrorism, ed. James K. Wither and Sam Mullins (Sofia: Procon, 2016), https://doi.org/10.11610/ctt.book. 
why of terrorism and OC. This is followed by a discussion of the crime-terror nexus and the concept of "convergence," i.e. the relationships between the two. The chapter then concludes with a brief discussion of implications for counter-terrorism (CT) and law enforcement (LE).

\section{Similarities and Differences}

By systematically breaking down the similarities and differences between terrorists and criminals we can gain a better appreciation of who they are, what they do, how they operate and why they do what they do. We can then better understand the parallels between these two worlds as well as the potential for cooperation.

\section{Profiles}

It is often thought that factors which seem to protect against involvement in crime (namely, being married, better educated and of higher occupational status), fail to reduce the likelihood of involvement in terrorism. ${ }^{2}$ On the one hand, higher socioeconomic status may reduce the motivation to engage in criminal activity for financial gain, while being married can counter negative social influence. By contrast, the ideological/political motives of terrorists appear to override these factors. Nevertheless, this overlooks the tremendous diversity among both terrorists and criminals. The bottom line is that while the single biggest risk-factor for involvement in either terrorism or crime is being a young male, there is no unique demographic profile of either population and there is a great deal of overlap between the two.

\section{Methods}

To appreciate the extent of overlap in terms of terrorist and criminal methodology, it is useful to begin by breaking down the different types of crime that terrorists engage in, in order to achieve different objectives:

\section{Inherent/violent}

Acts of terrorism inherently involve a variety of different criminal offences relating to the use of violence, often including (but not limited to) murder, assault, threatening behavior, property damage, kidnap and weapons / explosives offences. In fact, because the majority of terrorist behaviors are already proscribed in law, there is an argument to be made that specialized CT legislation is unnecessary. While this is open to debate, there is no doubt that organized criminals commit all of these same offences. However, criminal use of violence, generally speaking, is more discriminate ${ }^{3}$ and more deliberately covert,

2 Andrew Silke, "Holy Warriors: Exploring the Psychological Processes of Jihadi Radicalization," European Journal of Criminology 5, no.1 (2008): 99-123.

3 Louise I. Shelley and John T. Picarelli, "Methods Not Motives: Implications of the Convergence of International Organized Crime and Terrorism," Police Practice and Research: An International Journal 3, no. 4 (2002): 305-318. 
whereas terrorists strive for publicity. In connection with this (as discussed below) the motivation or purpose is also different.

\section{Preparation / Facilitation}

Terrorists must frequently break the law in order to prepare or facilitate attacks. Offences here can include arms trafficking, forgery, immigration violations, smuggling, and corruption. When it comes to these, and other ostensibly non-violent crimes aimed at making attacks possible, terrorists are much more similar to criminals in the sense that they want to remain "under the radar."

\section{Funding}

Much of the discussion of terrorists' involvement in crime tends to focus on crimes committed for financial gain. Although drug-trafficking is the most lucrative and widely documented criminal endeavor that terrorists are involved in, other profitable offences include kidnap-for-ransom (KFR), smuggling, robbery, extortion, fraud, counterfeiting, theft, trading in illicit goods, illegal mining and money laundering. Indeed, since the apparent decline of state sponsorship, terrorists have become increasingly self-reliant and engage in just about every criminal act imaginable in order to fund their operations. The only real difference compared to organized criminals is how the money is spent.

\section{Specialized terrorism offences}

Despite the fact that much of what terrorists do is already covered by "ordinary" legislation, in a number of countries specialized crimes have been created in order to deal with behaviors which are more or less unique to terrorism. These include training for terrorist purposes, membership in a terrorist organization, possession of terrorist-related documents or other materials, preparing or conspiring to commit an act of terrorism, encouragement, incitement or glorification of terrorism, fundraising for terrorism (which might otherwise involve legal means), and providing material support to terrorist organizations. Some of these offences have very close parallels in ordinary legislation - for example, incitement of hatred or violence, and conspiracy. However, the "terrorist" component ties these offences to legal definitions of terrorism and specific, designated organizations. Together, specialized terrorism offences enable prosecution of a broader range of behaviors and often denote added severity (and therefore harsher punishments) for actions which may still have a rough equivalent in ordinary criminal law. Perhaps most importantly, specialized legislation facilitates pre-emptive arrest and prosecution before an attack takes place.

\section{Public Relations / Vigilantism}

Because terrorists often want to gain support from a certain constituency, they will sometimes commit crimes which are at least partially aimed at increasing their own popularity and legitimacy. For example, both republican and loyalist 
paramilitaries in Northern Ireland engaged in vigilante "policing" within their communities, subjecting drug-dealers, joy-riders and other "anti-social" criminals to various punishments including beatings, maiming, murder and sometimes banishment from the country. ${ }^{4}$ Similarly, organized crime groups such as the mafia have been reported to police their own neighborhoods. ${ }^{5}$ In more advanced cases, vigilantism becomes governance, as for example with the "justice" administered by the "Islamic State" (ISIS) and Jabhat Fateh al-Sham (JFS) in Syria and Iraq.

\section{Miscellaneous / Spontaneous / Unrelated Offences}

Terrorists are only human. As a result, they sometimes commit miscellaneous offences during the commission of terrorist operations, or while going about their daily lives. In particular, traffic offences, from failing to pay for insurance, to speeding or running a red light can sometimes bring them into contact with law enforcement and potentially compromise their security. For instance, a plot to attack an English Defence League (EDL) demonstration in the UK was discovered purely by chance in June 2012 after an alert traffic policeman stopped a suspicious vehicle and found that it was uninsured. ${ }^{6}$

\section{Previous Criminal Records}

A final issue worth mentioning involves previous criminal offences. Much has been made of the fact that significant numbers of terrorists are ex-convicts or were radicalized and recruited from within prison while serving time for unrelated crimes. 'Ordinary' criminals may indeed be vulnerable to recruitment by terrorists given that they are socially marginalized and have ample reason to be angry at the state. Groups such as ISIS clearly recognize this and have successfully tailored "redemption narratives" designed to appeal to those with a criminal past. ${ }^{7}$ For terrorists, recruiting criminals makes sense since they may have specialized skills that can be applied to all manner of terrorist activity, from fundraising and facilitation to conducting attacks. Nevertheless, although radicalization and recruitment do take place to varying extents within prisons, and many terrorists do indeed have criminal records, they are not, generally

4 Rachel Monaghan, “'An Imperfect Peace': Paramilitary 'Punishments' in Northern Ireland," Terrorism and Political Violence 16, no. 3 (2004): 439-61.

5 See Hollianne Elizabeth Marshall, "Defended Neighborhoods and Organized Crime: Does Organized Crime Lower Street Crime?" (Master's Thesis, University of Central Florida, 2009), accessed May 17, 2015, http://etd.fcla.edu/CF/CFE0002751/ Marshall_Hollianne_E_200908_MA.pdf.

6 "Six Admit Planning to Bomb English Defence League Rally," BBC News, April 30, 2013, accessed May 17, 2015, http://www.bbc.com/news/uk-22344054.

7 Rajan Basra, Peter Neumann, and Claudia Brunner, Criminal Pasts, Terrorist Futures: European Jihadists and the New Crime-Terror Nexus (London: International Centre for the Study of Radicalisation, 2016), accessed October 30, 2016, http://icsr.info/ wp-content/uploads/2016/10/ICSR-Report-Criminal-Pasts-Terrorist-Futures-

European-Jihadists-and-the-New-Crime-Terror-Nexus.pdf. 
speaking, career criminals. The majority of them do not appear to have criminal records and among those who do, it is frequently for relatively petty and nonviolent offences. ${ }^{8}$ There is also little evidence to suggest that terrorists attempt to recruit prisoners or ex-convicts over and above anyone else, given that "cleanskins" (people with no prior convictions and unknown to security services) are perhaps even more valuable. Above all, terrorists are opportunists and will recruit whoever and however they can.

\section{Organization}

When we think about organizations we tend to think of hierarchical, bureaucratic structures like the police or military. Numerous terrorist organizations have modelled themselves after armies and have adopted strict lines of authority based on rank - among them the Provisional Irish Republican Army (PIRA), the Liberation Tigers of Tamil Eelam (LTTE), the Lord's Resistance Army (LRA) and the Revolutionary Armed Forces of Colombia (FARC). ${ }^{9}$ The Colombian Medellin and Cali cartels, which were dominant during the 1970s and 1980s, are often described in similar terms. ${ }^{10}$ Indeed, most, if not all, relatively large terrorist and criminal organizations have designated leaders. However, contemporary groups of both kinds have adopted less formal, more fluid network structures which defy easy classification and allow for significant autonomy among lower and mid-level operatives. ${ }^{11}$ This evolution is at least partially a reaction to successful CT and LE efforts ${ }^{12}$ and has also been facilitated by advances in travel and communications technology. Perhaps most importantly in the context of this discussion, networked systems of organization are not only more resistant to offensive operations, but also increase the potential for collaboration among terrorist and criminal actors as a result of increased autonomy. ${ }^{13}$

8 See for example, Sam Mullins, 'Home-Grown' Jihad: Understanding Islamist Terrorism in the US and UK (London: Imperial College Press, 2016).

9 We should not assume, however, that these organizations have been equally successful in implementing military systems of organization, or that they have remained stable over time - see, for example, Vera Eccarius-Kelly, "Surreptitious Lifelines: A Structural Analysis of the FARC and the PKK," Terrorism and Political Violence 24, no. 2 (2012): 235-58.

10 Jana S. Benson and Scott H. Becker, "The Organizational Structure of International Drug Smuggling," Journal of Criminal Justice 38, no. 2 (2010): 130-38.

11 John Picarelli, "Osama bin Corleone? Vito the Jackal? Framing Threat Convergence through an Examination of Transnational Organized Crime and International Terrorism," Terrorism and Political Violence 24, no. 2 (2012): 180-98.

12 Michael Kenney, "From Pablo to Osama: Counter-Terrorism Lessons from the War on Drugs," Survival 45, no.3 (2003): 187-206.

13 Picarelli, "Osama bin Corleone?" 


\section{Motives}

As with offender characteristics and systems of organization, there is considerable overlap in terrorist and criminal motivations. To begin with, both are primarily group-based activities and, as such, there are important social motives for both joining and staying involved in terrorism and crime, including friendship, solidarity, belonging and status. ${ }^{14}$ Perhaps the number one risk-factor for becoming involved in either type of activity is having terrorist/criminal family members or friends. In the short-term, terrorists and criminals also commit many of the same crimes for the same reasons - at least as far as fundraising goes. Whether it be drug-trafficking, bank robbery or any other form of crime that provides profit, they both want to make money.

The difference, of course, lies in the long-term. Terrorists want to commit high-profile attacks aimed at gaining publicity and eventually bringing about some form of social and political change. At the same time, they often believe that they are acting on behalf of a particular social group whom they wish to protect or liberate and therefore frequently express altruistic intentions. By comparison, criminals seem to be concerned almost exclusively with selfish gains and have no apparent interest in either publicity or politics, unless it can benefit them financially. Mexican cartels frequently behead their rivals, leave the dismembered corpses in public places, distribute videos of the execution taking place and make overt claims of responsibility. However, there is no clear political motivation and the violence is instrumental, aimed at intimidating their opponents and protecting their "turf." ${ }^{15}$ Similarly, although organized crime groups do occasionally assassinate politicians or other prominent officials, it is invariably meant to protect themselves and their illicit enterprises from being shut down. It is thus the political/ideological end-goals of terrorists that represent the critical difference between them and criminals.

\section{The Crime-Terror Nexus and "Convergence"}

In its broadest sense, the "crime-terror nexus" simply refers to any and all connections between terrorists and crime. At least four overlapping types of relationship can be identified: ${ }^{16}$

14 Sam Mullins, "Parallels Between Crime and Terrorism: A Social-Psychological Perspective," Studies in Conflict and Terrorism 32, no. 9 (2009): 811-30.

15 For a detailed discussion, see Phil Williams, "The Terrorism Debate over Mexican Drug Trafficking Violence," Terrorism and Political Violence 24, no. 2 (2012): 259-78.

16 This classification draws upon Glenn Curtis and Tara Karacan, The Nexus Among Terrorists, Narcotics Traffickers, Weapons Proliferators, and Organized Crime Networks in Western Europe (Washington, DC: Federal Research Division, Library of Congress, 2002); and Phil Williams, "Organized Crime and Terrorism," Latin American and Caribbean Center (2014), accessed May 23, 2015, https://lacc.fiu.edu/research/ publications/working-paper-2-williams.pdf. 
1. Interaction, where terrorists and criminals either work together somehow, or else compete or come into conflict with one another;

2. Appropriation, where one incorporates the methods of the other (i.e. where terrorists rely on their own "in-house" criminal capabilities, or where criminals use the tactics of terrorism);

3. Assimilation, where "hybrid" organizations emerge, which regularly engage in both terrorism and crime to the extent that it is difficult to say which is predominant; and

4. Transformation, where a change in identity occurs, so that one becomes the other.

\section{Interaction}

There are numerous anecdotal examples of interaction between terrorists and criminals. A recent study of 2,700 illicit actors spread across 122 countries found that 46 percent of terrorists' connections were to people involved in other illegal activities. ${ }^{17}$ Similarly, according to the Drug Enforcement Administration (DEA), close to half of US-designated Foreign Terrorist Organizations have ties to drug traffickers. ${ }^{18}$ Although the focus tends to be on cooperation, interactions vary significantly. They may be cooperative, exploitative or competitive; short or long-term; small or large-scale; voluntary or involuntary; direct or indirect; deliberate or unwitting. During the early 1980s, at a time when both groups were under pressure, the Italian Red Brigades (BR) sought the help of the Naples Camorra and the two groups reportedly assisted one another in the kidnapping of a senior politician and several assassinations. ${ }^{19}$ In the case of Northern Ireland, there was clear conflict between paramilitaries and criminals. At the same time, there were allegations that the PIRA used its vigilante activities as a pretext to control the drug market, providing "licenses" to selected dealers whom they allowed to continue operating, whilst simultaneously wiping out their competitors. ${ }^{20}$ Along similar lines, the Paraguayan People's Army (EPP) is believed to tax the cultivation of drugs within its territory, whilst also providing protection to drug traffickers in exchange for arms. ${ }^{21}$ Meanwhile, the

17 Scot Helfstein with John Solomon, Risky Business: The Global Threat Network and the Politics of Contraband (West Point, NY: Combating Terrorism Center, 2014), accessed May 25, 2015, https://www.ctc.usma.edu/wp-content/uploads/2014/05/Risky Business_final.pdf.

18 Douglas Farah, "Fixers, Super Fixers and Shadow Facilitators: How Networks Connect," International Assessment and Strategy Center (2012), 2, accessed May 25, 2015, http://www.strategycenter.net/docLib/20120423_Farah_FixersSuperFixers Shadow.pdf.

19 Chris Dishman, "Terrorism, Crime and Transformation," Studies in Conflict and Terrorism 24, no. 1 (2001): 53-54.

20 John Horgan and Max Taylor, "Playing the 'Green Card' - Financing the Provisional IRA: Part 1," Terrorism and Political Violence 11, no. 2 (1999): 30-31.

21 Marguerite Cawley, "Narcos Exchanging Arms for Protection from Paraguay's EPP: Officials," InSightCrime, August 27, 2013, accessed August 28, 2013, 
oft-cited nexus between terrorism and crime in West Africa is generally viewed as evidence of cooperation between Latin American drug traffickers and alQaeda in the Islamic Maghreb (AQIM). In reality, however, it seems that the latter may simply be taxing the former. ${ }^{22}$

While the relationships may not be entirely harmonious, terrorists are often reliant on criminal actors for goods or services. The illicit networks which make the trafficking of drugs, arms or other contraband possible are highly complex and adaptable. Within these networks, "fixers" and "facilitators" with specialized knowledge, connections and capabilities often play particularly important roles in connecting all types of terrorists and criminals to international markets. ${ }^{23}$ Arms dealers, smugglers, money launderers, purveyors of false documents and corrupt/sympathetic officials are some of the key contacts that terrorists are likely to rely upon. For instance, the FARC was able to acquire weapons from Australian arms dealers by way of an individual named José Luis Merino - a former commander of the El Salvadorian Communist Party with ties to El Salvador's political leadership. ${ }^{24}$ More recently, the "Islamic State" (IS) has relied upon various human traffickers, smugglers and corrupt border guards in order to help facilitate the entry of foreign fighters to the "caliphate," ${ }^{25}$ as well as the external flow of oil ${ }^{26}$ and looted artifacts ${ }^{27}$ to regional and international markets.

As this brief discussion illustrates, the interactions between terrorists and criminals are varied, complicated, dynamic and difficult to accurately discern. Nevertheless, it appears that interactions are more often tactical, born of necessity or circumstance and relatively short-term, as opposed to long-term and strategic.

\section{Appropriation}

The direct involvement of terrorists in criminal activity is perhaps the most widespread aspect of the crime-terror nexus. Besides their somewhat ambiguous relationship with the drug trade, during the mid-1990s the PIRA was able to bring in somewhere between US \$6-\$15 million a year, largely from criminal

http://www.insightcrime.org/news-briefs/narcos-exchanging-arms-for-protectionwith-paraguays-epp-officials.

Williams, "Organized Crime and Terrorism," 4.

Farah, "Fixers, Super Fixers and Shadow Facilitators."

24

25 Hannah Lucinda Smith, "The Jihadi Transporter," Vice, January 31, 2014, accessed January 31, 2014, http://www.vice.com/read/meeting-the-jihadi-transporter. Empire: How Captured Oilfields Fuel Isis Insurgency," The Guardian, November 19, 2014, accessed November 19, 2014, http://www.theguardian.com/world/2014/nov/ 19/-sp-islamic-state-oil-empire-iraq-isis.

27 Simon Cox, "The Men Who Smuggle the Loot That Funds IS," BBC News, February 17, 2015, accessed February 17, 2015, http://www.bbc.com/news/magazine-31485439. 
exploits. ${ }^{28}$ Illegal activities included robbery, KFR, extortion, "legitimate" businesses (e.g. security companies, taxi cab firms, restaurants and pubs), money lending, smuggling of contraband, video and audio piracy, welfare fraud and money laundering. ${ }^{29}$ Notably, however, the group was always acutely aware of the potential damage to their reputation that could result from being exposed as criminals and went to great pains to obscure and publicly deny these activities. $^{30}$

Islamist terrorists have also engaged in a great deal of criminality in order both to fund and facilitate their operations. Supporters of al-Qaeda (AQ) based in Europe and North America established a number of highly lucrative "charities" that in reality were sending funds to militant organizations in places like Afghanistan and Chechnya. ${ }^{31}$ In addition, they were adept at many other types of fraud and forgery of false documents. ${ }^{32}$ Similar activities continue today, and an estimated 40 percent of jihadist terrorist plots in Europe are believed to be financed by petty crime. ${ }^{33}$ In one recent example, a group of suspected jihadists in Britain had been calling pensioners over the phone and impersonating policemen in order to trick their victims into divulging their bank details, netting more than $£ 280,000$ in the process. ${ }^{34}$

On the other side of the crime-terror equation, organized crime groups (OCGs) also utilize tactics of terrorism when it suits their purposes. The aforementioned use of beheadings and assassinations to eliminate and intimidate rival gangs and government authorities are prime examples. OCGs have utilized improvised explosive devices in a similar way. For example, the Colombian Medellin and Cali cartels frequently used car bombings during their 1988-1993 internecine war, while contemporary Mexican cartels were responsible for at least 21 car bombings from 2010-2012, mostly targeting police. ${ }^{35}$ However, while criminals sometimes exhibit the same behavior as terrorists, they rarely share the same motives. It is far more common for terrorists to appropriate

28 Horgan and Taylor, "Playing the 'Green Card'," 10.

29 Horgan and Taylor, "Playing the 'Green Card'."

30 Ibid.

31 See, for example, "Transcript of Attorney General John Ashcroft Regarding Guilty Plea by Enaam Arnaout," US Department of Justice, February 10, 2003, accessed June 12, 2013, http://www.justice.gov/archive/ag/speeches/2003/021003agenaam aranouttranscripthtm.htm.

32 See, for example, Sean O'Neill, "Algerians 'Used Card Fraud to Fund Jihad'," The Telegraph, February 6, 2003, accessed June 22, 2015, http://www.telegraph.co.uk/ news/uknews/1421201/Algerians-used-card-fraud-to-fund-jihad.html.

33 Basra, Neumann and Brunner, Criminal Pasts, Terrorist Futures.

34 Arthur Martin and Richard Spillett, "Conned by Jihadi Cold Callers: Yard Reveals Pensioners are Being Fleeced out of Savings by ISIS Backers," The Daily Mail, March 5, 2015, accessed March 5, 2015, www.dailymail.co.uk/news/article-2979381/Counterterror-police-arrest-three-men-cold-call-scam-targeting-elderly-victims.html.

35 Robert J. Bunker and John P. Sullivan, "Cartel Car Bombings in Mexico," Letort Papers (Carlisle, PA: Strategic Studies Institute and US Army War College Press, 2013). 
criminal methodologies (ranging from ad-hoc, individual crimes to enduring, organized conspiracies), rather than the other way around.

\section{Assimilation}

Several terrorist organizations have become so successful in their criminal activities that they are often accused of being just as, if not more, concerned with making money than achieving their ideological goals. In the case of the Afghan Taliban, "[s]ome observers argue that that the line between the definition of Taliban member and drug smuggler is blurring' as Taliban commanders become more directly involved in the trade-running their own heroin laboratories, for example-and are more motivated by profits and power than ideological considerations. In this way, the definitional boundaries between 'insurgent' and 'organised criminal group' begin to collapse." ${ }^{36}$ Similar claims have been made about the FARC, which reportedly made somewhere in the region of \$2.4-\$3.5 billion a year from the cocaine trade, ${ }^{37}$ and the Abu Sayyaf Group (ASG) in the Philippines, which has continually fluctuated between terrorism and banditry over time. ${ }^{38}$ Although clearly a deeply ideological group, it could also be argued that IS qualifies as a hybrid organization, given the millions of dollars it generates through a combination of oil smuggling, extortion and trading in illegal antiquities. From the other end of the spectrum, the closest example of a criminal-terror group is Dawood Ibrahim's D-Company, which was responsible for perhaps the most dramatic instance of criminal use of terrorism in history - the Bombay bombings of 1993 (see Case Study 1 below).

D-Company, like other hybrid organizations, has not lost its original identity, nor indeed, have the Taliban, FARC, ASG or IS. The degree to which any hybrid is a terrorist or criminal organization is always open to some debate. Regardless of the final verdict, these groups should be of more or less equal concern to both LE and CT.

\section{Transformation}

The fourth possible type of relationship between terrorism and crime is the least clearly documented and most open to interpretation. It is sometimes suggested that the FARC and ASG fall into this category; however, this overlooks the fact that they still clearly retain their respective political/religious identities and continue to pursue an ideological agenda. The FARC is currently in the final stages of an ongoing peace process with the Colombian government, while ASG

36 David Bewley-Taylor, "Drug Trafficking and Organised Crime in Afghanistan," The RUSI Journal 158, no. 6 (2013): 9.

37 John Otis, "The FARC and Colombia's Illegal Drug Trade," Wilson Center Latin American Program, November 2014, 9, accessed May 24, 2015, www.wilsoncenter.org/ sites/default/files/Otis_FARCDrugTrade2014.pdf.

38 McKenzie O'Brien, “Fluctuations Between Crime and Terror: The Case of Abu Sayyaf's Kidnapping Activities," Terrorism and Political Violence 24, no. 2 (2012): 32036. 


\section{Case Study 1. D-Company.}

D-Company is an international crime syndicate founded in Mumbai in 1976 by Dawood Ibrahim. In the mid-1980s, pressure from the Indian authorities forced Ibrahim to re-locate to Dubai. Here he was able to take advantage of a more permissive environment and D-Company expanded its operations to include smuggling, weapons and drug trafficking, extortion, protection rackets and illegal hawala transfers. 39

During the early 1990s, D-Company switched from purely profit-driven activities as the group developed a radical Islamist agenda. ${ }^{40}$ This was apparently driven by Ibrahim's anger at what he believed was the persecution of Indian Muslims by the Hindu majority. D-Company's first overt involvement in terrorism was a series of bombings on March 12, 1993 in Mumbai, which killed 257 people, injured hundreds more and caused billions of Rupees worth of damage. Ibrahim is alleged to have both financed and organized the operation. D-Company's involvement in terrorism continued and in 2003 the US labeled Ibrahim a Specially Designated Global Terrorist due to his suspected cooperation with AQ and Lashkar e-Taiba (LeT). Among other operations, the group is believed to have provided logistical support to the LeT assault on Mumbai in November 2008. ${ }^{42}$ At the same time, D-Company continues to operate as a transnational criminal syndicate covering Asia, Africa and the Middle East.

has pledged allegiance to IS. Another possible candidate for "transformation" is the group behind the 2004 Madrid train bombings. This operation succeeded thanks to the radicalization and recruitment of a former drug-dealer named Jamal Ahmidan who used his criminal connections to secure funding as well as the stolen dynamite used in the attacks. ${ }^{43}$ However, there is a difference between transformation at the individual level (i.e. radicalization of individual criminals) and organizational transformation. The former process is quite common, while the latter is much rarer and usually open to debate.

39 Ryan Clarke and Stuart Lee, "The PIRA, D-Company, and the Crime-Terror Nexus," Terrorism and Political Violence 20, no. 3 (2008): 385.

40 Clarke and Lee, "The PIRA, D-Company, and the Crime-Terror Nexus," 385, 390.

41 Ryan Clarke, "Lashkar-i-Taiba: The Fallacy of Subservient Proxies and the Future of Islamist Terrorism in India," Letort Papers (Carlile, PA: Strategic Studies Institute and US Army War College Press, 2010), accessed May 24, 2015, http://www.strategicstudiesinstitute.army.mil/pubs/display.cfm?pubID=973.

42 See, for example, Thomas Burghardt, "Organized Crime, Intelligence and Terror: The D-Company's Role in the Mumbai Attacks," Centre for Research on Globalization, December 13, 2008, accessed June 14, 2015, http://www.globalresearch.ca/ organized-crime-intelligence-and-terror-the-d-company-s-role-in-the-mumbaiattacks/11385.

43 Williams, "Organized Crime and Terrorism," 8-9. 
Northern Ireland is again relevant in this context, where-more than 15 years since the Good Friday Agreement-paramilitary groups remain deeply entrenched in organized crime. As the Independent Monitoring Commission noted in 2011, "Some members and former members of all groups remain heavily involved in a wide range of serious crime, exploiting the contacts and expertise they acquired during the Troubles and thereby presenting a challenge to law enforcement which is significantly more serious than it would otherwise have been." ${ }^{44}$ Nevertheless, politically motivated violence continues and it would be an over-simplification to suggest that either republican or loyalist organizations were nothing more than OCGs. With this in mind, there may be a greater risk of transformation occurring in societies that are transitioning away from conflict. Under such circumstances, armed groups may have ostensibly demobilized, but clandestine structures are left intact and are able to morph into heavily armed and well-trained OCGs. This appears to have been the case in El Salvador and Guatemala and may develop further in Colombia as the peace process with FARC comes to an end. ${ }^{45}$

In conclusion, although there is no clear analytical boundary between any of the four types of relationship discussed here, the dividing line between assimilation and possible transformation is particularly difficult to determine.

\section{Convergence of Terrorism and Crime?}

The term "convergence" implies that terrorist involvement in crime is increasing. There is reason to believe that this has occurred to some extent, at least in terms of interaction and appropriation. Following the relative decline in state sponsorship of terrorism since the end of the Cold War, terrorists today must be self-reliant in order to survive. The increased "criminalization" of terrorism has also been facilitated by the shift towards decentralized network structures of both types of organization along with increased opportunities for criminal activity, in particular within conflict zones. Besides these global developments, there are sometimes more specific indicators of terrorists' increasing involvement in crime. For example, the prominent jihadist ideologue Abu Qatada went to considerable effort to justify and sanction murder, stealing, cheating, fraud, kidnap and rape. ${ }^{46}$ More recently, the degree of overlap between jihadi terrorist and criminal networks in Europe appears to have become "more pronounced, more visible and more relevant" than in the past - at least partly due

44 Independent Monitoring Commission, Twenty-Sixth and Final Report of the Independent Monitoring Commission (London: The Stationery Office, 2011), 57, accessed May 26, 2015, http://cain.ulst.ac.uk/issues/politics/docs/imc/imc040711.pdf.

45 See, for example, Douglas Farah, "Central America's Northern Triangle: A Time for Turmoil and Transitions," PRISM 4, no. 3 (2013): 97.

46 Omar Othman (aka Abu Qatada) v. Secretary of State for the Home Department, Special Immigration and Appeals Commission, Appeal No. SC/15/2005, February 26, 2007, 8-9, accessed April 1, 2010, http://www.icj.org/IMG/QATADA.pdf. 
to the appeal of the aforementioned narratives of redemption. ${ }^{47}$ Increased criminality may also be brought about by the killing of terrorist leaders who are then replaced by less ideological, more pragmatic individuals - as appears to have been the case with ASG in the Philippines. ${ }^{48}$

Despite such developments, we must bear in mind that there are also potential barriers to increased convergence of terrorism and crime. Although it is clearly not a universal deterrent, the risk of getting caught increases substantially both when terrorists commit crime by themselves and when they cooperate with criminals who do not share their ideology. As PIRA clearly recognized, getting caught not only jeopardizes an organization's operations, but also risks undermining its legitimacy and popular support. Under the same circumstances, criminals open themselves up to greater scrutiny and heftier punishments. Perhaps more importantly, terrorists and criminals will only continue to cooperate as long as they both continue to gain somehow, and as long as they are able to trust one another. As an Italian policeman once commented on the alliance between the Red Brigades and Camorra, "We don't think any such alliance will work because, while they have a common enemy in the police and the establishment, their aims and ideological beliefs are so vastly different ... their alliance at best would be superficial and short-lived because neither of them would want to compromise the group's secrets." ${ }^{49}$

Taking all of these different factors into account, it is clear that terrorist appropriation of criminal skills is now the norm. But although certain OCGs do show similarities to terrorists, there is little to suggest that criminal use of terrorist tactics is increasing. Furthermore, although examples of interaction between terrorists and criminals are not hard to come by, in general, it is far from clear that these interactions are becoming deeper, longer-lasting or more prevalent. In other words, it is not apparent that terrorist and criminal organizations are merging with one another on a global scale to create new "super threats." Similarly, when it comes to assimilation and especially transformation (described above), there is a very short list of potential candidates that fall into these categories and little to indicate that these are the new norm.

In the final analysis, it is essential that we do not over-generalize. Terrorist involvement in crime (and vice versa) varies tremendously from group to group and over time and is largely dictated by geographic opportunities, changing political landscapes and interpersonal connections. Rather than think in terms of a global convergence of terrorism and crime, it is enough to simply be aware of the fact that all terrorism relies on criminal activity to some extent andwhether or not this involves collaboration with otherwise independent criminal actors - this presents us with both challenges and opportunities for LE and CT.

\footnotetext{
47 Basra, Neumann and Brunner, Criminal Pasts, Terrorist Futures, 3.

48 O'Brien, "Fluctuations Between Crime and Terror."

49 Dishman, "Terrorism, Crime and Transformation," 54.
} 


\section{Implications for Law Enforcement and Counter-Terrorism}

There is increasing recognition of the need to coordinate initiatives to combat the nexus between terrorism and OC. One way of doing this is to make crimeterror interaction or appropriation less profitable and more risky for the individuals and organizations involved. However, these objectives cannot be achieved if agencies dedicated to fighting OC and terrorism remain "stovepiped," either domestically or internationally. Effective strategies require the exchange of information, interagency/inter-departmental cooperation, adequate resources and appropriate legal frameworks. Just as OCGs and terrorists learn from, and sometimes assist one another, so too can LE and CT professionals.

Indeed, this already occurs in a variety of ways. For instance, in December 2009 security services in Australia were investigating an Afghan-Australian named Milad bin Ahmad-Shah al-Ahmadzai, who was in communication with Anwar al-Awlaki and had expressed a desire to go and fight in Afghanistan. ${ }^{50}$ It soon emerged that Ahmadzai was also involved in serious criminal activity. As a result, CT investigators worked jointly with the Criminal Investigations Department (CID) over a period of several months and Ahmadzai (who had been placed on a terrorism watch-list in the meantime) was eventually convicted for taking part in a ram raid, threatening to kill an intelligence officer and attempted murder. ${ }^{51}$

As the above case demonstrates, crime committed by terrorists provides authorities with important opportunities for intervention and prosecution, especially when CT and CID personnel are able to work together. However, it should be recognized that this is not always the case and in fact different agencies or departments frequently compete with one another for the same resources. Indeed, it was recently reported that counter-organized crime efforts in Australia and Canada have suffered because resources have been poured into $\mathrm{CT}^{52}$ On the one hand, this is understandable, given that terrorism is a top

50 "Bail Refused for Man After Terror Arrest," Nine News, May 28, 2013, accessed October 31, 2016, http://news.ninemns.com.au/national/2013/05/28/16/13/counterterror-police-arrest-sydney-man.

51 Sarah Crawford, "Aarows Nightclub Shooting: Al-Ahmadzai Found Guilty of Gay Sex Club Murder Attempt," Daily Telegraph, March 4, 2016, accessed October 31, 2016, http://www.dailytelegraph.com.au/news/nsw/extremist-guilty-of-sex-club-murderattempt/news-story/8c65e12043449a9b9489b26a3217db1a; Interview conducted with investigating officer, May 7, 2012.

52 Colin Freeze, "Terrorism Investigations Tax RCMP's Ability to Fight Canada's Organized Crime," Globe and Mail, October 21, 2016, accessed October 31, 2016, www.theglobeandmail.com/news/national/organized-crime-wiretaps-plummet-asrcmp-priorities-shift-to-terrorism/article32483434/; Flynn Murphy, "Alarm Over Terrorism Leads Australian Police to Take Eyes off Organised Crime Groups," Telegraph, July 6, 2015, accessed October 31, 2016, www.telegraph.co.uk/news/worldnews/ australiaandthepacific/australia/11720754/Alarm-over-terrorism-leads-Australianpolice-to-take-eyes-off-organised-crime-groups.html. 
priority. On the other hand, it could lead to missed opportunities for interdicting terrorists or their support networks that are involved in organized crime.

Furthermore, while crime and terrorism are very much transnational, CT and LE responses still tend to be predominantly national and are limited by a continuing reluctance to share information across national jurisdictions, particularly when it is classified. ${ }^{53}$ National police forces also remain hard pressed to counter terrorists and OCGs that are sometimes better equipped, better armed and more agile than themselves. There is thus a clear need for improved interagency and international cooperation and capacity building. ${ }^{54}$ Some have even suggested creating regional (e.g. European ${ }^{55}$ ) or even global agencies that would have the necessary authority and resources at their disposal to tackle both transnational $\mathrm{OC}$ and terrorism. ${ }^{56}$ Of course numerous bodies already exist, which attempt to deal with both types of threat - among them the US Drug Enforcement Administration (DEA) (see Case Study 2 below).

Despite ongoing difficulties, the proliferation of joint task forces and intelligence fusion centers since 2001 has provided opportunities for much closer cooperation between agencies involved in LE and CT. This has produced "cross trained" professionals that can operate in both worlds. In the US, cooperation between government agencies is enhanced by organizations such as the Office of Terrorism and Financial Intelligence (TFI) within the Treasury Department. This involves a series of interrelated bureaus and offices designed to combat threats related to crime, terrorism and the closely associated problem of corruption. ${ }^{57}$ The TFI maintains links with international agencies such as Interpol, Europol and the Financial Action Task Force (FATF).

At the international level, a range of different agencies are working to address the threat of crime-terror linkages. The United Nations Office on Drugs and Crime (UNODC) is a major player and offers a broad range of assistance that includes practical support for CT legislation, counter illicit trafficking measures and anti-money laundering and corruption initiatives. In 2002, Interpol created a Fusion Task Force to address the linkages between crime and ter-

53 A Dangerous Nexus: Crime, Conflict, and Terrorism in Failing States (International Peace Institute, 2013), 4, accessed June 8, 2015, http://www.ipinst.org/2013/11/ a-dangerous-nexus-crime-conflict-and-terrorism-in-failing-states. It is worth stressing that unwillingness to share information may be entirely justified in cases where corruption fostered by $\mathrm{OC}$ has permeated senior levels of the government and security forces.

54 Colin Clarke, "Drugs \& Thugs: Funding Terrorism through Narcotics Trafficking," Journal of Strategic Security, 9 no.3 (2016): 1-15.

55 Judy Dempsey, "Time for an EU Counterterrorism Agency," Carnegie Europe, April 21, 2016, accessed October 30, 2016, http://carnegieeurope.eu/strategiceurope/ ?fa $=63401$.

56 A Dangerous Nexus: Crime, Conflict, and Terrorism in Failing States.

57 "Terrorism and Financial Intelligence," US Department of the Treasury, June 28, 2013, accessed June 8, 2015, http://www.treasury.gov/about/organizationalstructure/offices/Pages/Office-of-Terrorism-and-Financial-Intelligence.aspx. 
rorism and provide data that could assist LE agencies to disrupt and dismantle criminal entities that support terrorism. However, Interpol, like the UN, depends on contributions from member states, which often fail to provide sufficient information, and its budget remains constrained.

\section{Case Study 2. The Drug Enforcement Administration.}

The DEA was founded in 1973 to enforce federal drug laws. It did not become an integral part of the US "war on terror" until after 9/11, when it received substantial increases in funding, manpower and intelligence gathering capabilities. ${ }^{58}$ The DEA's operations against "narco-terrorism" are led by its Special Operations Division (SOD). This unit comprises two dozen partner agencies, including the FBI, CIA, NSA, Internal Revenue Service and the Department of Homeland Security. The SOD forwards information from wiretaps, intercepts and databases from various sources to federal agents and local LE officials. SOD agents have also coordinated "sting" operations against so-called king-pin, crime-terror facilitators notably arms dealers Viktor Bout and Monzer al-Kassar. ${ }^{59}$ In addition, the DEA has developed enforcement capabilities in the form of Foreign-deployed Advisory and Support Teams (FASTs). These ten-man teams are trained by US Special Forces in small unit tactics and close-quarters battle and are interoperable with elite military units.

FASTs were originally developed for operations in Afghanistan, where the DEA has been active for more than a decade. The main purpose of DEA operations there is "to deny narcotics-generated funding to terrorism and the insurgency," while seeking more broadly to reduce drug trafficking and combat corruption. ${ }^{60}$ However, as the US presence has reduced, the DEA has focused on developing the capability and capacity of specialized vetted units of the Counternarcotics Police Afghanistan (CNP-A), in particular the National Interdiction Unit (NIU) and the Sensitive Investigative Unit (SIU). ${ }^{61}$ Strong relationships with foreign counterparts in Afghanistan and elsewhere remain an essential feature of DEA operations. This kind of ability to work jointly, across international boundaries with a variety of law enforcement, intelligence and military organizations, and to take swift, decisive action against terrorists and criminals alike will be essential to disrupting transnational terrorism and organized crime in the $21^{\text {st }}$ century.

58 Malcolm Beith, "A Single Act of Justice: How the Age of Terror Transformed the War on Drugs," Foreign Affairs, September 8, 2013, accessed June 14, 2015, https://www.foreignaffairs.com/articles/americas/2013-09-08/single-act-justice.

59 Johnny Dwyer, "The DEA's Terrorist Hunters: Overreaching Their Authority," Time, August 8, 2011, accessed June 15, 2015, http://content.time.com/time/world/ article/0,8599,2087220,00.html; Farah, Fixers, Super Fixers and Shadow Facilitators.

60 Statement of James L. Capra, Chief of Operations DEA Before the House Committee on Foreign Affairs Subcommittee on the Middle East and North Africa, "Future US Counternarcotics Efforts in Afghanistan," February 5, 2014, 1, accessed June 15, 2015, http://docs.house.gov/meetings/FA/FA13/20140205/101709/HHRG-113-FA13Wstate-CapraJ-20140205.pdf.

61 Ibid., 3-5. 
International cooperation and coordination to address the crime-terror nexus remains a work in progress. However, initiatives cannot be limited to operational matters such as border security and improvements in intelligence sharing and policing. The international community broadly recognizes that more comprehensive strategies are needed to tackle governance, economic and social issues that make so many states vulnerable to criminal and terrorist activity.

\section{Conclusion}

Much of the discussion of the crime-terror nexus tends to focus upon terrorist fundraising and cooperation with OCGs. However, it is important to bear in mind that terrorists engage in a wide range of criminal activity for a variety of reasons and their involvement in crime is not limited to cooperation with separate criminal entities. Indeed, of the four different types of relationship identified, appropriation appears to be just as, if not more common than interaction. Above all, however, it is vital to realize that the nexus between crime and terrorism is not uniform across the globe but varies from country to country and over time. When it comes to addressing this problem, although there have been some encouraging developments, there are still many ongoing challenges, not least of them being bureaucratic boundaries between different organizations. Looking for more effective ways of disrupting the crime-terror nexus and using it to our advantage should be a priority in CT. 


\section{About the authors}

Sam Mullins is Professor of Counterterrorism and Academic Advisor, Senior Executive Seminar, at the George C. Marshall European Center for Security Studies. He came to the Marshall Center in October 2012 from the Centre for Transnational Crime Prevention at the University of Wollongong in Australia, where he remains an honorary fellow. Dr. Mullins has delivered professional training seminars at the senior level for a variety of government agencies including the FBI, the Australian Federal Police, the Canadian Security Intelligence Service, the Chinese Ministry of Public Security, and the Indonesian National Armed Forces. He has lectured on terrorism and counterterrorism at the master's level since 2009, primarily for military, law enforcement, and security professionals from around the globe. Dr. Mullins is the author of Home-Grown Jihad: Understanding Islamist Terrorism in the US and UK and is co-editor of the book Combating Transnational Terrorism, which was published in February 2016.

James K. Wither James K. Wither is Professor of National Security Studies at the George C. Marshall European Center for Security Studies, where he has been a member of the PTSS faculty since 2008. He is a retired British Army Officer and former researcher in Twentieth Century Warfare at the Imperial War Museum, London. He has taught or presented terrorism-related subjects at a wide variety of institutions, including the FBI Academy, the UK Defence Academy, the NATO School, the Geneva Centre for Security Policy, and the Afghan Army Staff College. Professor Wither is co-editor of the book Combating Transnational Terrorism, which was published in February 2016. His areas of expertise include contemporary armed conflict and terrorism; the organization, structure, and role of armed forces; national security and defense strategy; theory and practice of negotiations; and PME. 